\title{
Attitudes and Personal Attributes Regarding Patient Receptivity towards the Participation of Medical Students in Gynecological Consultations: A Cross-Sectional Study
}

\section{Atitudes e atributos pessoais relativos à receptividade das pacientes à participação de estudantes de medicina em consultas ginecológicas: Um estudo de corte transversal}

\author{
Miriam da Silva Wanderley ${ }^{10}$ Dejano Tavares Sobral ${ }^{1}$ Brenda Alves de Oliveira Lima ${ }^{1}$ \\ Maria Elisa de Bessa Freire ${ }^{1}$ Mariana Albuquerque Campos da Silva ${ }^{1}$ \\ Marina Prado e Silva Gonçalves Rosa ${ }^{1}$ Thaís Ferreira Souza ${ }^{1}$
}

\footnotetext{
${ }^{1}$ Area of Gynecology and Obstetrics, Faculdade de Medicina, Universidade de Brasília, Brasília, DF, Brazil
}

Rev Bras Ginecol Obstet 2019;41:613-620.
Address for correspondence Miriam da Silva Wanderley, MD, PhD, Departmento de Ginecologia e Obstetrícia, Faculdade de Medicina, Universidade de Brasília, Brasília, DF, 70210-900, Brazil (e-mail: miriamsw@unb.br).

\begin{abstract}
Keywords

- healthcare

- medical student

- gender

- outpatient care

- gynecology
\end{abstract}

Objective To evaluate the association between the acceptance on the part of the patients and their reasons to consent to or refuse medical student attendance during gynecological outpatient care, considering the participants' demographic characteristics, consultation experience, and gender bias or lack thereof.

Methods Face-to-face interviews with patients waiting for gynecological consultations that had been scheduled in advance at Hospital Universitário de Brasília. Contingency analyses were used to determine the levels of association among the patient variables. The accepted significance level was values of $p<0.05$.

Results We interviewed 469 patients. The comfort level with the presence of a student was strongly related to the number of students present during the consultation (Cramér $V=0.671$ ). The inclination to grant consent (a series of reasons to consent to or refuse student attendance) was significantly related $(p<0.001)$ to the overall receptivity to student participation $(\rho=0.482)$, the positive appraisal of student-doctor demeanor in previous consultations ( $\rho=0.253, N=408)$, and to greater levels of schooling $(\rho=0.158)$. The patients' receptivity was significantly related $(p<0.001)$ to the lack of bias regarding the gender of the physician (Cramér $V=0.388$ ), previous experience with students (Cramér $V=0.235$ ) and awareness of the fact that they would be present (Cramér $V=0.217$ ), older age $(p=0.136, p=0.003)$, and multiparity $(p=0.102, p=0.027)$.

Conclusion Greater receptivity to student participation related significantly to five conditions in decreasing order of strength of association: lack of bias regarding the gender of the Ob-Gyn, previous experience with student involvement, awareness of the received

June 25, 2018

accepted

August 12, 2019
DOI https://doi.org/

10.1055/s-0039-1697984. ISSN 0100-7203.
Copyright (e 2019 by Thieme Revinter

Publicações Ltda, Rio de Janeiro, Brazil
License terms

(c) (1) 


\section{Resumo}

\author{
Palavras-chave \\ - atenção à saúde \\ - estudante de \\ medicina \\ - gênero \\ - atendimento \\ ambulatorial \\ - ginecologia
}

\begin{abstract}
presence of students, older age, and multiparity. We also found that a more positive inclination to consent to student attendance correlated positively with a greater receptivity to student participation and to a suitable student-doctor demeanor.
\end{abstract}

Objetivo Avaliar a associação entre as razões das pacientes para consentir ou recusar a presença de estudantes de medicina no ambulatório de Ginecologia, considerando seus fatores demográficos, experiência prévia com alunos, e sensibilidade com relação ao gênero.

Métodos Entrevistas com as pacientes que aguardavam consultas ginecológicas previamente agendadas no Hospital Universitário de Brasília. Análises de contingência foram utilizadas para determinar os níveis de associação entre as variáveis das pacientes. Valores de $p<0.05$ foram considerados estatisticamente significativos.

Resultados Foram entrevistadas 469 pacientes. Observou-se forte associação entre o conforto com a presença do estudante e o número destes presentes à consulta ( $V$ de Cramér $=0.671$ ). A tendência ao consentimento (relação de motivos para consentir ou discordar da presença do estudante) relacionou-se significativamente $(p<0.001)$ à maior receptividade à participação dos alunos $(\rho=0.482)$, a uma avaliação positiva do comportamento aluno-médico em consultas anteriores ( $\rho=0.253, N=408$ ), e a maior escolaridade das pacientes ( $\rho=0.158)$. Observou-se associação significativa entre receptividade das pacientes $(p<0.001)$ e ausência de discriminação quanto ao gênero do médico ( $V$ de Cramér $=0.388$ ), experiência prévia com estudantes ( $V$ de Cramér $=0.235)$, ciência de que estariam presentes à consulta $(V$ Cramér $=0.217)$, idade mais avançada ( $\rho=0.136 ; p=0.003)$, e multiparidade $(\rho=0.102 ; p=0.027)$.

Conclusão Maior receptividade à participação dos estudantes relacionou-se a cinco condições em ordem decrescente de força de associação: ausência de discriminação quanto ao gênero do médico ginecologista-obstetra, experiência prévia com estudantes, conhecimento antecipado sobre a presença deles, idade mais avançada, e multiparidade. Também foi observada correlação positiva entre maior tendência ao consentimento e maior receptividade à participação dos alunos e comportamento adequado médico-estudante.

\section{Introduction}

The participation of medical students in gynecologic consultations appears to be critical for an effective educational experience in women's medicine. Crucially, such experiences enable the enhancement of the clinical skills of the students through patient interaction and by partaking in gynecological care under the careful guidance of the medical team. As a result, the students will hopefully be able to meet women's health needs as future primary care physicians.

Therefore, the willingness of the women to consent to student engagement during consultations is critical. However, student participation in gynecological care creates a difficult interpersonal situation given the intimate nature of the clinical procedures. Not all patients are willing to have medical students present during their appointments, and this mostly depends on the age, expectations, and willingness of the women. ${ }^{1-4}$ Moreover, gender bias commonly occurs, and restrictions regarding the assistance of male students in gynecological care lead to adverse outcomes, as several authors have reported..$^{5-7}$
Additionally, most patients in these reports voice a preference for a female obstetrics-gynecology (Ob-Gyn) physician. ${ }^{8,9}$ Underlying their gender preference (among other reasons), many women may hold a negative stereotype of male Ob-Gyn physicians, which is related to their expectations regarding their desired gynecological care. ${ }^{10}$

Barriers to student participation and gender bias could thwart not only the adequate clinical training but also the student's choice to specialize in Ob-Gyn. Any such tendency could be detrimental in times of increased demand for women's health services. A recent report ${ }^{11}$ from our institution revealed a significant decrease in the number of male, but not female, graduates that chose an Ob-Gyn medical residency over a twodecade period. ${ }^{11}$ One could ask whether a generational trend among patient attitudes was related to the decline in the specialty's popularity.

The purpose of the present study was to analyze the relationship between patient acceptance (receptivity) and their reasons to consent to or refuse student attendance during gynecological outpatient care, while considering the 
participants' demographic characteristics, consultation experience, and gender bias.

\section{Methods}

A cross-sectional study was undertaken at the gynecological outpatient unit of Hospital Universitário de Brasília (HUB). We interviewed 471 women who had a medical appointment for any condition over 24 nonconsecutive weeks during 2016and 2017. No exclusion criteria were employed based on demographic characteristics or diagnoses, but two cases were excluded because of failure to answer critical questions. All of the patients that were contacted agreed to participate in the survey. Patients aged $\geq 18$ years signed an informed consent form, and those under 18 years of age signed an assent form, as did their parents.

Based on a literature review, ${ }^{1,4,12-14}$ we developed and pretested 29 outpatient volunteers with a 32 -item questionnaire in face-to-face interviews while they waited in the appointment room. The instrument included questions about demographic features, the number of their consultations attended by medical students, their previous experiences with medical students attending a consultation, whether they had received previous information about the presence of medical students, how comfortable they were with the prospect of student attendance, permission for a gynecological examination, if they felt comfortable refusing, and their gender preference regarding their Ob-Gyn physician. The demographic features included age, marital status, parity, schooling, and family monthly income based on the Brazilian monthly minimum wage. In 2016, the monthly minimum wage was $\mathrm{R} \$ 880.00$ ( US\$271.60), and in 2017, it was R\$937.00 ( US\$289.00).

The questionnaire also included 16 Likert-type questions (with results that range from 5 [strongly agree] to 1 [strongly disagree]) from which we tallied three composite variables. There were six questions about the patients' reasons to refuse student attendance, four on the reasons to consent to it, and six on their appraisal of the students' professional (student-doctor behavior) demeanor in a previous consultation. The student deportment questions included whether the student had asked for permission and showed respect, care, responsibility, communication, and social skills.

Frequency distributions were used to summarize the categorical data. After an analysis of the main components (in which we found a unique component that explained over $40 \%$ of the variance in each case), we tallied 3 composite variables using the sum of the participants' responses to the respective questions. The composite variables (and their respective standardized Cronbach $\alpha$ values) included a 6item index of student-doctor demeanor $(\alpha=0.81)$, a 6 -item index of the motivations for refusal $(\alpha=0.71)$ and a 4 -item index of the motivations for consent $(\alpha=0.62)$.

We also defined two emergent variables: the first was an index of the patients' receptivity to student participation in their gynecological care, which was tallied by adding the dichotomous responses to the following three ways of acceptance: the comfort with student presence $(1=$ at ease with either male or female students); the number of students allowed in the consultation ( $1=3$ or more students); and a pelvic examination performed by a student of any gender ( $1=$ acceptance). The other emergent variable was the consent inclination index, which was tallied as the difference between the indexes of the reasons for consent and refusal (adjusted to the respective number of questions).

The International Business Machines Statistical Package for the Social Sciences (IBM SPSS Statistics, IBM Corp., Armonk, NY, US) software was used to process the data. The analyses included correlation and crosstabs statistics to measure the relationships and compare the proportions among the identified variables. We reported the measures of association as effect sizes, namely, the values for Cramér V or Spearman $\rho$. Values of $p<0.05$ were considered statistically significant.

The Committee of Ethics in Research in Human Beings of Faculdade de Medicina da Universidade de Brasília approved the study (1.126.648).

\section{Results}

The patients had a mean age of $43.06 \pm 14.1$ years (range: $12-$ 78). Among them, $53.4 \%$ were married, $27.4 \%$ were unmarried, and the remaining $19.1 \%$ were divorced or widowed. A total of $21.7 \%$ were nulliparous, $61.4 \%$ had given birth 1 to 3 times, and $16.8 \%$ had given birth 4 or more times. As for schooling, $23.9 \%$ had higher education, $38.6 \%$ had finished high school, and the level of schooling of the remaining $37.5 \%$ was only up to junior high school. Regarding family income, $63.9 \%$ earned less than 3 times the monthly minimum wage, $26.3 \%$ earned 3 or 4 times the monthly minimum wage, and $9.8 \%$ earned 5 or more times the monthly minimum wage. A majority $290(61.7 \%)$ of the participants had attended 4 or more previous appointments in the outpatient unit, and only 73 (15.7\%) were attending an appointment for the first time.

A total of 384 (81.9\%) participants reported having previous consultation experiences with a medical student. Among them, more than 396 (96\%) agreed (formally and/or strongly) that they had observed 5 of the 6 aspects that compose the student-doctor demeanor during an earlier appointment. However, $74(18.1 \%)$ of those women did not agree with the statement: 'The student (she or he) requested the patient's permission to participate in the consultation.' Additionally, only 227 (48.4\%) of the 469 patients asserted that they could refuse student participation in their gynecological care if they wanted to.

Most patients ( $n=331,70.6 \%$ ) felt at ease with the prospect of students, male or female, attending their gynecological consultation. A lower proportion ( $n=86,18.3 \%$ ) only felt at ease with females, while a minority $(n=51,10.9 \%)$ felt uneasy with students of any gender, and the single remaining patient was only comfortable with the presence of male students. We reclassified this case into the first group during further analyses. This grouping regarding the level of comfort (three groups: no student, female only, and any gender) was significantly related to the patients' previous consultation experience (no $=0$; yes $=1$ ) with a student in attendance (Cramér $\mathrm{V}=0.155 ; p=0.003 ; N=469$ ). The third group (any 
Table 1 Association of the patients' comfort level with the prospect of student presence in the consultation and the number of students that they allowed to attend $(n=469)$

\begin{tabular}{|l|l|l|l|l|}
\hline \multirow{2}{*}{ Comfort level } & \multicolumn{3}{|l|}{$\begin{array}{l}\text { Acceptable number } \\
\text { of students }\end{array}$} & \multirow{2}{*}{ Total } \\
\cline { 2 - 4 } & $\begin{array}{l}\text { None } \\
(\%)\end{array}$ & $\begin{array}{l}\text { One or } \\
\text { two (\%) }\end{array}$ & $\begin{array}{l}\text { Three or } \\
\text { more (\%) }\end{array}$ & \\
\hline $\begin{array}{l}\text { At ease with a male } \\
\text { or female student }\end{array}$ & $0(0.0)$ & $\begin{array}{l}155 \\
(46.7)\end{array}$ & $\begin{array}{l}177 \\
(53.3)\end{array}$ & 332 \\
\hline $\begin{array}{l}\text { At ease only with } \\
\text { female students }\end{array}$ & $0(0.0)$ & $\begin{array}{l}59 \\
(68.6)\end{array}$ & $\begin{array}{l}27 \\
(31.4)\end{array}$ & 86 \\
\hline $\begin{array}{l}\text { Uneasy either with } \\
\text { male or female } \\
\text { students }\end{array}$ & $\begin{array}{l}45 \\
(88.2)\end{array}$ & $4(7.8)$ & $2(3.9)$ & 51 \\
\hline Total & 45 & 218 & 206 & 469 \\
\hline
\end{tabular}

Note: Measure of association: Cramér $\mathrm{V}=0.671 ; p<0.001$.

gender) had six times more experience than the novice participants.

The grouping according to the level of comfort showed a strong association (Cramér $\mathrm{V}=0.671 ; p<0.001 ; N=469$ ) with the number of students that the patients allowed to attend the consultation, as reported in - Table 1. Greater acceptance of student involvement was linked to lack of gender bias, as $37.7 \%$ (177/469) of the participants were at ease with either male or female students, and were tolerant of 3 (or more) students being in the consultation room.

Moreover, the relationship between the grouping by level of comfort and the patients' acceptance or refusal to undergo a pelvic examination performed by a student was significantly linked to gender (Cramér $\mathrm{V}=0.276 ; p<0.001$; $N=468)$. Although most participants $(275,58.8 \%)$ said they would be at ease with students and would consent to be examined by either male or female students, 40 patients (8.5\%) only allowed female attendance and examination. The patients' stance on pelvic examination performed by a student was also significantly related to the number of students that they allowed in the consultation room (Cramér $\mathrm{V}=0.191 ; p<0.001)$. The significant interrelationships among the three facets of student acceptance supported the creation of a composite variable index of receptivity, as described in the Methods section of the present paper.

The grouping by level of comfort also showed a significant association with the patients' gender preference (male, female, or either one) for Ob-Gyn physician (Cramér $\mathrm{V}=0.262$; $p<0.001 ; N=469)$. Notably, 294 patients $(62.7 \%)$ had no gender preference regarding the Ob-Gyn physician or the student involved in the appointment. In contrast, 38 patients (8.1\%) had a preference for a female Ob-Gyn physician and only felt at ease with female students during their consultations.

Most participants agreed with the four reasons to consent to student attendance during their consultation. - Table $\mathbf{2}$ shows their responses (dichotomized between agreement or disagreement). The first reason (students helping in the consultation) was the most discriminant in the relationships between the consenting responses and the patients' stance on the acceptance of a pelvic examination performed by a student.

Furthermore, the participants mostly disagreed with the six reasons to refuse student attendance. The reasons for refusal (dichotomized between disagreement or not) and their percentages of agreement are shown in - Table 3 . Shame or fear of the pelvic examination was the most discriminant in the relationships between the reasons for refusal and the patients' stance regarding acceptance of a pelvic examination performed by a student.

Based on the patients' dichotomized opinions on three ways of acceptance (as reported in the Methods section), we generated the following four-level index of receptivity to student engagement among the 469 participants. The levels of receptivity were either 0 (no-way; $n=63 ; 13.4 \%$ ), 1 (one-way; $n=89 ; 19.0 \%$ ), 2 (two-way; $n=162 ; 34.5 \%$ ), or 3 (three-way; $n=155 ; 33.0 \%$ ). The receptivity index correlated positively with the index of reasons for consent $(\rho=0.314 ; p<0.001$;

Table 2 Relationships between the patients' agreement with the reasons to consent to student attendance at a consultation and their ordered stance on the acceptance of a pelvic examination performed by a student $(n=468)$

\begin{tabular}{|c|c|c|c|c|c|}
\hline \multirow{2}{*}{$\begin{array}{l}\text { Reasons for consent } \\
\text { (percentage of agreement) }\end{array}$} & \multicolumn{3}{|c|}{ Acceptance of pelvic examination } & \multirow[t]{2}{*}{ Cramér V } & \multirow[t]{2}{*}{$p$-value } \\
\hline & $\begin{array}{l}\text { Neither by male or } \\
\text { female students, } n \text { (\%) }\end{array}$ & $\begin{array}{l}\text { Only by female } \\
\text { students, n (\%) }\end{array}$ & $\begin{array}{l}\text { Either by male or } \\
\text { female students, } \mathrm{n}(\%)\end{array}$ & & \\
\hline $\begin{array}{l}\text { Students' help in } \\
\text { the consultation, } \\
412(88.0 \%)\end{array}$ & $23(67.6)$ & $75(79.8)$ & $314(92.4)$ & 0.233 & $<0.001$ \\
\hline $\begin{array}{l}\text { Expecting students } \\
\text { attendance, } \\
432(92.3 \%)\end{array}$ & $28(82.4)$ & $81(86.2)$ & $323(95.0)$ & 0.168 & 0.001 \\
\hline $\begin{array}{l}\text { Learning about } \\
\text { her own health, } \\
421(90.0 \%)\end{array}$ & $26(76.5)$ & $81(86.2)$ & 314 (97.9) & 0.150 & 0.005 \\
\hline $\begin{array}{l}\text { Wishing to help in } \\
\text { student education, } \\
452(96.6 \%)\end{array}$ & $33(97.1)$ & 86 (91.5) & 333 (97.9) & 0.141 & 0.010 \\
\hline
\end{tabular}

Note: Within each stance group on the examination by a student, the rows show the number and percentage of participants who did agree (formally and/or strongly) with the given reason on each stance regarding the pelvic examination. 
Table 3 Relationships between the patients' agreement with a reason to refuse student attendance at a consultation and their ordered stance on the acceptance of a pelvic examination performed by a student $(n=468)$

\begin{tabular}{|c|c|c|c|c|c|}
\hline \multirow{2}{*}{$\begin{array}{l}\text { Reasons for refusal } \\
\text { (percentage of agreement) }\end{array}$} & \multicolumn{3}{|c|}{ Acceptance of pelvic examination } & \multirow[t]{2}{*}{ Cramér V } & \multirow[t]{2}{*}{$p$-value } \\
\hline & $\begin{array}{l}\text { Neither by male or } \\
\text { female students, } \\
\mathrm{n}(\%)\end{array}$ & $\begin{array}{l}\text { Only by female } \\
\text { students, } \\
\text { n (\%) }\end{array}$ & $\begin{array}{l}\text { Either by male or } \\
\text { female students, } \\
\text { n (\%) }\end{array}$ & & \\
\hline $\begin{array}{l}\text { Feeling shame in examination } \\
\text { by a male student, } \\
182(38.9 \%)\end{array}$ & $22(64.7)$ & $79(84.0)$ & $81(23.8)$ & 0.512 & $<0.001$ \\
\hline $\begin{array}{l}\text { Privacy during pelvic examination } \\
\text { by an Ob-Gyn physician, } 212(45.3 \%)\end{array}$ & $25(73.5)$ & $71(75.5)$ & $116(34.1)$ & 0.366 & $<0.001$ \\
\hline $\begin{array}{l}\text { Feeling shame in examination } \\
\text { by a female, student } \\
71(15.2 \%)\end{array}$ & $14(41.2)$ & $26(27.7)$ & $31(9.1)$ & 0.288 & $<0.001$ \\
\hline Students' lack of expertise, 160 (34.2\%) & $22(64.7)$ & $45(47.9)$ & $93(27.4)$ & 0.249 & $<0.001$ \\
\hline $\begin{array}{l}\text { Privacy during dialogue with } \\
\text { an Ob-Gyn physician, } \\
190(40.6 \%)\end{array}$ & $23(67.6)$ & $50(52.2)$ & $117(34.4)$ & 0.216 & $<0.001$ \\
\hline $\begin{array}{l}\text { Lingering of consultation because } \\
\text { of student attendance, } \\
139(29.7 \%)\end{array}$ & $16(47.1)$ & $34(36.2)$ & $89(26.2)$ & 0.137 & 0.012 \\
\hline
\end{tabular}

Note: Within each stance group on the examination by a student, the rows show the number and percentage of participants who did agree with the given reason to refuse students attendance at the consultation.

$N=469$ ), negatively with the index of motives for refusal ( $\rho=$ -0.453; $p<0.001 ; N=469$ ), and again positively with the measure of inclination to consent to student attendance $(\rho=$ $0.482 ; p<0.001 ; N=469$ ). Additionally, receptivity had a significant relationship with previous experience with (Cramér $\mathrm{V}=0.235 ; p<0.001$ ) and previous knowledge of (Cramér $\mathrm{V}=0.217 ; p<0.001$ ) student attendance.

Consistently, the participants' index of receptivity to student involvement related to their stance regarding the gender of the Ob-Gyn physician 10 (2.1\%) of male preference, 81 (17.3\%) of female preference and 378 (80.6\%) of no gender preference; $N=469$ ). The relationship between three ways of acceptance and gender bias regarding the Ob-Gyn physician (dichotomized as bias or no bias) was quite strong (Cramer's $V=0.388 ; p<0.001 ; N=469$ ). These data are presented in -Table 4.

Notably, the measure of inclination to consent correlated positively with the score for student-doctor demeanor $(\rho=$

Table 4 Relationship of the patients' gender bias regarding the Ob-Gyn physician with the index of receptivity to student participation in the gynecological consultation

\begin{tabular}{|l|l|l|l|}
\hline \multirow{2}{*}{$\begin{array}{l}\text { Three ways of } \\
\text { acceptance index } \\
\text { (ways of acceptance) }\end{array}$} & \multicolumn{2}{|l|}{ Ob-Gyn gender bias } & \multirow{2}{*}{ Total } \\
\cline { 2 - 3 } & Bias, n (\%) & No bias, n (\%) & \\
\hline 0. No-way & $33(52.4)$ & $30(47.6)$ & 63 \\
\hline 1. One-way & $27(30.3)$ & $62(69.7)$ & 89 \\
\hline 2. Two-way & $20(12.3)$ & $142(87.7)$ & 162 \\
\hline 3. Three-way & $11(7.1)$ & $144(92.9)$ & 155 \\
\hline Total & 91 & 378 & 469 \\
\hline
\end{tabular}

Note: Measure of association: Cramér V=0.388; $p<0.001$.
0.253; $p<0.001 ; N=408$ ); namely, a stronger difference in motivation for consent was significantly related to a better appraisal of the students' demeanor during the consultation in previous outpatient appointments. Finally, the indexes of inclination to consent and receptivity displayed distinct relationships with the demographic features. Inclination to consent correlated positively with schooling $(\rho=0.158$; $p=0.001 ; N=469)$ and with family income ( $\rho=0.175$; $p<.001 ; N=460)$. Receptivity showed weak associations with age $(\rho=0.135 ; p=0.003 ; N=469)$ and parity $(\rho=$ $0.114 ; p=0.027 ; N=469)$.

\section{Discussion}

A crucial part of the education of medical students is learning through interaction and direct contact with the patients. Over the years, this involvement has been viewed positively ${ }^{5}$ both by students and patients. However, as the intimacy level increases, the patients' willingness decreases, ${ }^{5}$ which is particularly true for a gynecological clinical history and physical examination and may lead women to refuse student attendance.

From this point of view, our finding of a greater acceptance of student participation in gynecological consultations (as shown by the relationship between the stances regarding the possible level of comfort and the number of students that are allowed to attend) is noteworthy and seems consistent with the findings of other studies. ${ }^{1,4,12-14}$

The level of acceptance could derive from situational and sociocultural factors. We suggest that in the context of outpatient gynecological care, the patients' combined affective and cognitive reasons for refusal or consent to student attendance drive the components of receptivity to student 
participation. The patients' levels of informed experience, gender bias, and socioeconomic background moderate these relationships.

Our results indicate the positive influence of background familiarity: ill-advised and inexperienced women were less receptive to the students than informed and seasoned women, which is in agreement with other studies. ${ }^{1,3,5,15,16} \mathrm{We}$ observed a higher rate of acceptance of student presence among patients who knew in advance that students may attend, as described in other reports. ${ }^{3,17}$ Other authors noticed that, in addition to a greater level of acceptance, the patients also allowed a higher level of student participation in subsequent visits. ${ }^{5}$

Additionally, the amount of previous experience with students, regardless of gender, seemed to matter. Reciprocal altruism could be at work in the patient-student relationship. We found that most women valued the students' help with the consultation and wished to contribute to the learning of futures doctors, which is in agreement with other studies. ${ }^{1-3,13,14}$

The specific context of outpatient care as a public service in a teaching hospital also seems to be influential. The patients may feel obligated to give their consent and show willingness, and even expect student involvement, in return for the free-of-charge care provided by the staff and students. However, in a study by Berry et al, ${ }^{13}$ fewer than half of the patients anticipated that students would be involved in the medical consultations or were aware that their physician could be a professor, despite being in a teaching hospital. Moreover, Ching et $\mathrm{al}^{4}$ demonstrated a high acceptance rate of student involvement in private schools.

In addition, the health staff could probably help set up a favorable environment for student participation in a healthcare unit by providing patients with information and by introducing the student. Mavis et $\mathrm{al}^{5}$ observed that the likelihood of a patient agreeing with student involvement was higher when the request came from the doctors themselves, a finding that further emphasizes the importance of the doctor-patient relationship on the student's education, which includes more than the acquisition of specific skills. Despite this, other authors have suggested that a non-physician should request permission so that the patient did not feel pressured to accept. ${ }^{13}$

In the context of the present study, we viewed receptivity as a combination of affective states that resulted from the patients' different opinions regarding student attendance. A patients' inexperience with trainees attending a consultation could lower their receptivity to student involvement, especially male students in gynecological care. Nonetheless, findings from the literature show that most women agree (even those that refuse student involvement) that the best way for the students to develop clinical skills is the effective participation in consultations with real patients, that is, the "hands-on" approach. ${ }^{2,14,16}$

The subjective feeling of many patients that males (students or physicians) have a lower understanding of the needs of women could also be at work. In the literature, the women's preference for female Ob-Gyn physicians has been associated with a negative stereotype about male Ob-Gyn physicians, hinging on the patients' expectations of their desired gynecologic care. ${ }^{10}$ The negative gender-role stereotype could be related to the supposed differences in empathy regarding men and women. ${ }^{18}$

However, regardless of the reason, studies have shown that male students have greater difficulty in acquiring experience in gynecological clinical practice. ${ }^{19,20}$ The higher proportion of refusals and the greater difficulty in obtaining consent compared with female students could lead to greater anxiety among male students, which could negatively affect their interactions with patients. ${ }^{20}$ Additionally, the quality of the clerkship experience could influence the students' choice of Ob-Gyn as a career. ${ }^{7}$

We surmise that some patients' uneasiness at the prospect of student attendance and the consequent refusal of an examination were associated with a fluid sense of being unprotected; this feeling was linked to personal beliefs (such as a need for privacy) and emotions (such as shame or fear), especially concerning male student involvement. However, we argue that physicians of any gender, if they have the proper training, can address such conditions to encourage the interaction between patients and students without gender bias.

Additionally, attention should be given to the differences in the level of comfort regarding gender of students and ObGyn among the patients; in our sample, the distribution was as follows: no gender preference (62.7\%), and preference for females $(8.1 \%)$. The frequency of gender bias regarding the the student and Ob-Gyn physician (preference for females) was higher among younger patients (12-26 years old) than among older patients, but it is not clear whether such opinions are subject to change. In a study by Fortier et al, ${ }^{21}$ the patients who changed their minds about accepting students were on average 10.2 years younger than those who didn't change their minds.

The results have been inconsistent regarding the association between demographic characteristics and acceptance of student attendance. Like other studies, ${ }^{14,19,22}$ we found a positive association with older age, while two studies ${ }^{1,3}$ found that the association was not significant ${ }^{3}$ or that it was with younger patients. ${ }^{1}$ We also found a significant relationship between acceptance and parity, which is in agreement with other authors, ${ }^{14,19}$ but not between acceptance and the patients' marital status, which is in disagreement with other studies. ${ }^{3,22}$

However, we cannot forget that $48.4 \%$ of the patients in our study felt that they could refuse the student if they wanted to, which was a better result than those reported by other authors, ${ }^{12,23}$ and $18.1 \%$ of the patients did not hear a request for permission from the student in attendance. These issues are of critical importance due to the clear need to demonstrate ethical values, to humanize medical education, and for the empowerment of women concerning their rights and choices.

It seems that there still is a misguided belief among physicians that they should not ask patients for permission out of a fear that they could refuse it, ${ }^{1,5}$ which appears to be based more on prejudice than on empirical evidence. ${ }^{17}$ It is vital for everyone involved in the educational process that this belief does not spread further. 
The present study had some limitations. The cross-sectional design and the use of a closed-question survey, which prevented the causal interpretation of the data, restricted its scope. Additionally, the use of a single-site report with patients using a public medical care service hinders the generalization of the findings. Moreover, as suggested by a recent report, ${ }^{24}$ there are many aspects to the interactions between patients and students, and we recognize that student engagement in outpatient care involves consent, care, and safety for the women involved, which are issues that were not framed in the survey.

We suggest that it is essential that medical staff and professors explain to patients the importance of their cooperation to the education of future physicians and request their cooperation in this process, without assuming that they are obliged to consent to it without asking for their permission, because in the end, amid so many variables, it seems that the decision to accept student participation involves a balance between altruistic intentions to contribute to the training of future physicians and the private nature of gynecological issues (clinical history and physical examination), as some authors have noted.,21 The performance of the medical staff and the absence of biased attitudes are crucial for the teaching of skills and abilities and for the transmission of ethical values, such as observing the autonomy of the patients and showing respect for them.

\section{Conclusion}

Greater receptivity to student participation related significantly to five conditions, in decreasing order of strength of association: lack of gender bias regarding the Ob-Gyn physician, previous experience with student involvement, previous information about student presence, older age, and multiparity. We also found that a more positive inclination to consent (that is, a higher motivation to consent and lower motivation do refuse) to student attendance correlated positively with a greater receptivity to student participation and suitable student-doctor demeanor.

\section{Contributions}

All of the authors contributed with the project and data interpretation, the writing of the article, the critical review of the intellectual content, and with the final approval of the version to be published.

\section{Conflicts to Interest}

The authors have none to declare.

\section{References}

1 Carmody D, Tregonning A, Nathan E, Newnham JP. Patient perceptions of medical students' involvement in their obstetrics and gynaecology health care. Aust N Z J Obstet Gynaecol 2011;51(06): 553-558. Doi: 10.1111/j.1479-828X.2011.01362.x

2 Hartz MB, Beal JR. Patients' attitudes and comfort levels regarding medical students' involvement in obstetrics-gynecology outpatient clinics. Acad Med 2000;75(10):1010-1014
3 Yang J, Black K. Medical students in gynaecology clinics. Clin Teach 2014;11(04):254-258. Doi: 10.1111/tct.12122

4 Ching SL, Gates EA, Robertson PA. Factors influencing obstetric and gynecologic patients' decisions toward medical student involvement in the outpatient setting. Am J Obstet Gynecol 2000;182(06):1429-1432. Doi: 10.1067/mob.2000.106133

5 Mavis B, Vasilenko P, Schnuth R, Marshall J, Jeffs MC. Medical students' involvement in outpatient clinical encounters: a survey of patients and their obstetricians-gynecologists. Acad Med 2006; 81(03):290-296

6 Chang JC, Odrobina MR, McIntyre-Seltman K. The effect of student gender on the obstetrics and gynecology clerkship experience. J Womens Health (Larchmt) 2010;19(01):87-92. Doi: 10.1089/jwh. 2009.1357

7 Jiang X, Altomare C, Egan JF, Tocco DB, Schnatz PF. The ObGyn clerkship: are students denied the opportunity to provide patient care and what is the role of gender? Conn Med 2012;76(04): 231-236

8 Janssen SM, Lagro-Janssen AL. Physician's gender, communication style, patient preferences and patient satisfaction in gynecology and obstetrics: a systematic review. Patient Educ Couns 2012;89 (02):221-226. Doi: 10.1016/j.pec.2012.06.034

9 Tobler KJ, Wu J, Khafagy AM, Pier BD, Torrealday S, Londra L. Gender preference of the obstetrician-gynecologist provider: a systematic review and meta-analysis. Obstet Gynecol 2016; 127:43S. Doi: 10.1097/01.AOG.0000483829.97196.8f

10 Buck KS, Littleton HL. Stereotyped beliefs about male and female OB-GYNS: relationship to provider choice and patient satisfaction. J Psychosom Obstet Gynaecol 2014;35(01):1-7. Doi: 10.3109 /0167482X.2013.866646

11 Wanderley MDS, Sobral DT. Ob-Gyn gender preferences of gynecology ambulatory patients and students' choice of the specialty. Rev Bras Ginecol Obstet 2017;39(12):645-646. Doi: 10.1055/s0037-1606840

12 Alawad AAM, Younis FH. Patients' attitude towards undergraduate medical students at university charity teaching hospital in Sudan. Int J Med (Dubai) 2014;2:28-31. Doi: 10.14419/ijm. v2i1.2264

13 Berry RE Jr, O'dell K, Meyer BA, Purwono U. Obtaining patient permission for student participation in obstetric-gynecologic outpatient visits: a randomized controlled trial. Am J Obstet Gynecol 2003;189(03):634-638. Doi: 10.1067/s0002-9378(03) 00876-7

14 Rizk DEE, Al-Shebah A, El-Zubeir MA, Thomas LB, Hassan MY, Ezimokhai M. Women's perceptions of and experiences with medical student involvement in outpatient obstetric and gynecologic care in the United Arab Emirates. Am J Obstet Gynecol 2002;187(04):1091-1100. Doi: 10.1067/mob.2002.126284

15 Ryder N, Ivens D, Sabin C. The attitude of patients towards medical students in a sexual health clinic. Sex Transm Infect 2005;81(05): 437-439. Doi: 10.1136/sti.2004.014332

16 Anfinan N, Alghunaim N, Boker A, et al. Obstetric and gynecologic patients' attitudes and perceptions toward medical students in saudi arabia. Oman Med J 2014;29(02):106-109. Doi: 10.5001/o mj.2014.26

17 Westberg K, Lynøe N, Lalos A, Löfgren M, Sandlund M. Getting informed consent from patients to take part in the clinical training of students: randomised trial of two strategies. BMJ 2001;323(7311):488-491. Doi: 10.1136/bmj.323.7311.488

18 Baez S, Flichtentrei D, Prats M, et al. Men, women...who cares? A population-based study on sex differences and gender roles in empathy and moral cognition. PLoS One 2017;12(06):e0179336. Doi: 10.1371 /journal.pone.0179336

19 O'Flynn N, Rymer J. Women's attitudes to the sex of medical students in a gynaecology clinic: cross sectional survey. BMJ 2002;325(7366):683-684

20 Akkad A, Bonas S, Stark P. Gender differences in final year medical students' experience of teaching of intimate examinations: a 
questionnaire study. BJOG 2008;115(05):625-632. Doi: 10.1111/ j.1471-0528.2008.01671.x

21 Fortier AM, Hahn PM, Trueman J, Reid RL. The acceptance of medical students by women with gynaecology appointments. JObstet Gynaecol Can 2006;28(06):526-530. Doi: 10.1016/ S1701-2163(16)32179-X

22 Ikeako LC, Adiuku-Brown A, Ezegwui HU, Onuh AC, Okeke TC. Attitudes of patients to medical students in the gynaecology clinic: a Nigerian experience. JAdv Med Med Res. 2016; 15:1-10. Doi: 10.9734/BJMMR/2016/25623

23 Abdulghani HM, Al-Rukban MO, Ahmad SS. Patient attitudes towards medical students in Riyadh, Saudi Arabia. Educ Health (Abingdon) 2008;21(02):69

24 Armitage AJ, Cahill DJ. Medical students and intimate examinations: What affects whether a woman will consent? Med Teach 2018;40(12):1281-1286. Doi: 10.1080/0142159X.2018.1428736 